\title{
PENGARUH PERCEIVED ORGANIZATIONAL SUPPORT DAN KOMITMEN ORGANISASIONAL TERHADAP TURNOVER INTENTION KARYAWAN AHIMSA BEACH VILLA JIMBARAN
}

\author{
I Putu Riska Andika Putra ${ }^{1}$ \\ I Gusti Ayu Manuati Dewi
}

${ }^{1}$ Fakultas Ekonomi dan Bisnis Universitas Udayana (Unud), Bali, Indonesia e-mail: andika_6des@yahoo.co.id

\begin{abstract}
ABSTRAK
Tujuan penelitian ini adalah untuk menganalisis pengaruh perceived organizational support dan komitmen organisasional terhadap turnover intention. Penelitian ini dilakukan di Ahimsa Beach Villa Jimbaran dengan sampel sebanyak 84 karyawan, yang ditentukan dengan teknik sampel jenuh. Pengumpulan data dilakukan dengan penyebaran kuesioner yang menggunakan skala Likert 5 poin. Teknik analisis yang digunakan adalah regresi linier berganda. Hasil penelitian menunjukkan bahwa pertama, perceived organizational support tidak berpengaruh secara signifikan terhadap turnover intention. Kedua, komitmen organisasional berpengaruh negatif dan signifikan terhadap turnover intention. Disarankan kepada pihak perusahaan untuk meningkatkan.

Kata kunci: perceived organizational support, komitmen organisasional, turnover intention
\end{abstract}

\begin{abstract}
The purpose of this study was to analyze the effect of perceived organizational support and organizational commitment to turnover intention. The study was conducted at Ahimsa Beach Villa Jimbaran with a sample of 84 employees, determined by saturated sample technique. Data collection was done by distributing questionnaires using 5-point Likert scale. The analysis technique used is multiple linear regression. The results show that first, perceived organizational support has no significant effect on turnover intention. Second, organizational commitment has a negative and significant effect on turnover intention. Suggested to the company to improve.

Keywords: perceived organizational support, organizational commitment, turnover intention
\end{abstract}


I Putu Riska Andika Putra, Pengaruh Perceived Organizational ...

\section{PENDAHULUAN}

Sumber daya manusia yang dimiliki oleh organisasi / perusahaan seharusnya berkualitas, sehingga perusahaan mampu bersaing dengan perusahaan-perusahaan lain. Jika pengelolaan sumber daya manusia tidak berjalan dengan efektif, maka akan muncul berbagai masalah yang akan mengganggu kinerja perusahaan (Khoiroh, 2012). Menurut Rahayu (2011) seringkali dalam perusahaan ada karyawan yang tidak mengerahkan seluruh kemampuan yang dimiliki untuk mencapai tujuan perusahaan karena adanya keinginan untuk pindah ke perusahaan lain atau disebut turnover intention.

Turnover dapat diartikan sebagai pergerakan yang dilakukan karyawan untuk keluar dari organisasi dan turnover yang tinggi juga menyebabkan kurang efektifnya sebuah organisasi karena hilangnya karyawan yang berpengalaman (Andini, 2006). Menurut Sutanto dan Gunawan (2013), turnover intention adalah kesadaran untuk memiliki keinginan mencari alternatif pekerjaan di organisasi lain. Turnover intention yang tinggi dapat menjadi suatu indikasi tingginya turnover karyawan, dan tingginya tingkat turnover telah menjadi masalah serius bagi banyak perusahaan. Handaru dan Nailul (2012) dijelaskan lebih lanjut bahwa beberapa perusahaan mengalami masalah ketika mengetahui proses rekrutmen yang telah berhasil menjaring staf yang berkualitas pada akhirnya menjadi sia-sia karena mereka memilih keluar dan bekerja pada perusahaan lain. Perceived organizational support merupakan persepsi karyawan mengenai sejauh mana perusahaan memberikan dukungan kepada mereka (Rhoades dan Eisenberger, 2002). Apabila seorang karyawan dalam sebuah organisasi dapat merasakan 
adanya dukungan dari organisasi yang sesuai dengan norma, keinginan, dan harapan yang dimiliki para karyawan, maka akan terbentuk sebuah kesadaran dari karyawan untuk memenuhi kewajibannya kepada organisasi, sehingga mereka tidak ingin meninggalkan organisasi karena telah memiliki ikatan emosional dan komitmen yang kuat terhadap organisasinya (Han dkk., 2012). Rhoades dan Eisenberger (2002) menyatakan bahwa POS memiliki pengaruh negatif terhadap turnover intention, karena karyawan menganggap penghargaan yang diberikan oleh organisasi merupakan keuntungan bagi mereka, seperti adanya perasaan diterima dan diakui, memperoleh gaji yang layak dan promosi, serta pemberian bentuk-bentuk bantuan lain yang diperlukan karyawan. Kondisi ini menyebabkan rendahnya keinginan karyawan untuk keluar dari organisasi.

Pengusaha harus mengupayakan agar karyawan secara emosional berkomitmen pada organisasi dan tidak punya niat untuk meninggalkan organisasi (Ponnu dan Chuah, 2010). Komitmen organisasional merupakan suatu keadaan dimana karyawan memihak organisasi tertentu serta tujuan-tujuan dan keinginannya untuk mempertahankan keanggotaanya dalam organisasi (Robbins dan Judge, 2009). Novaliawati dkk. (2013) mengemukakan bahwa komitmen organisasional merupakan loyalitas karyawan terhadap organisasi dan proses yang terus menerus terjadi dimana karyawan menunjukkan dan mengekspresikan perhatian atau hal yang penting terhadap organisasi. Sutanto dan Gunawan, (2013) menyatakan bahwa komitmen organisasional berpengaruh negatif terhadap turnover intention. Rendahnya komitmen yang dimiliki karyawan untuk memberikan kontribusi bagi kemajuan perusahaan merupakan salah satu faktor 
yang menyebabkan karyawan berkeinginan untuk keluar dari organisasi tempatnya bekerja sekarang.

Berdasarkan wawancara dan pengumpulan data awal di lapangan terlihat Ahimsa Beach Villa mengalami kondisi tingginya persentase karyawan yang keluar dari organisasi dalam tiga tahun terakhir, seperti pada Tabel 1. terindikasi bahwa terjadi kecenderungan peningkatan karyawan yang keluar dari perusahaan pada periode 2014-2016 yang mencapai puncaknya sebesar 13 persen pada tahun 2016

Tabel 1.

Tingkat turnover karyawan Ahimsa Beach Villa periode tahun 2014 sampai tahun 2016

\begin{tabular}{|c|c|c|c|c|c|c|c|}
\hline Tahun & $\begin{array}{c}\text { Jumlah } \\
\text { Karyawan } \\
\text { Awal } \\
\text { (2) }\end{array}$ & $\begin{array}{l}\text { Jumlah } \\
\text { Karyawan } \\
\text { Akhir } \\
\text { (3) }\end{array}$ & $\frac{(4)}{(2)+(3): 2}$ & $\begin{array}{c}\text { Karyawan } \\
\text { Keluar } \\
\text { (5) }\end{array}$ & $\begin{array}{c}\text { Presentase } \\
\text { Turnover } \\
(\%) \\
(6)^{*} \\
(5):(4) \times \\
100 \% \\
\end{array}$ & $\begin{array}{c}\text { Karyawan } \\
\text { Masuk } \\
\text { (7) }\end{array}$ & $\begin{array}{c}\text { Keinginan } \\
\text { Keluarnya } \\
\text { Karyawan } \\
\text { (8) }\end{array}$ \\
\hline 2014 & 100 & 92 & 9 & 8 & 8,3 & 4 & - \\
\hline 2015 & 96 & 86 & 91 & 10 & $10,9 \%$ & 12 & - \\
\hline 2016 & 98 & 86 & 92 & 12 & $13 \%$ & - & 11 \\
\hline
\end{tabular}

Sumber: Ahimsa Beach Villa Jimbaran, 2016

Menurut Widjaja dkk. (2008) turnover karyawan dikatakan normal berkisar antara 5-10 persen per tahun, dan tergolong tinggi apabila lebih dari 10 persen per tahun. Dari Tabel 1 dapat ditarik simpulan bahwa ada masalah turnover karyawan yang cukup serius karena dapat menimbulkan efek buruk bagi Ahimsa Beach Villa. Salah satunya yaitu adanya keinginan untuk mencari pekerjaan baru di perusahaan lain karena merasa kurang cocok, kecenderungan dari karyawan untuk berpikir keluar dari perusahaan karena tekanan dari atasan dan keinginan karyawan untuk meninggalkan perusahaan tersebut jika adanya kesempatan. Jika hal tersebut terus berkelanjutan, maka akan terjadi pemborosan biaya dalam 
proses perekrutan dan pelatihan karyawan baru. Dengan tingginya tingkat turnover pada tahun 2016 terbuka kemungkinan adanya peningkatan turnover intention pada tahun-tahun berikutnya pada karyawan di Ahimsa Beach Villa Jimbaran.

Berdasarkan latar belakang yang telah diuraikan diatas, maka penelitian ini bertujuan untuk menguji pengaruh perceived organizational support terhadap turnover intention dan pengaruh komitmen organisasional terhadap turnover intention karyawan di Ahimsa Beach Villa Jimbaran.

Perceived organizational support berpengaruh positif terhadap upaya dan hasil kerja karyawan sehingga membuat karyawan percaya bahwa usaha mereka dihargai di masa yang akan datang oleh organisasinya sendiri (Eisenberger et al., 1986). Dalam penelitian yang dilakukan oleh Maertz et al. (2007) karyawan yang merasa organisasinya memberi dukungan yang positif akan setia dan tetap tinggal di organisasi tersebut. Sebaliknya, jika organisasi tidak menunjukkan dukungan yang positif terhadap karyawannya, maka mereka akan cenderung meninggalkan organisasinya.

$\mathrm{H}_{1}$ : perceived organizational support berpengaruh negatif terhadap turnover intention

Sutanto dan Gunawan (2013) menemukan bahwa komitmen organisasional berpengaruh negatif dan signifikan terhadap turnover intention. Thakre (2015) menyatakan bahwa komitmen organisasional berpengaruh negatif terhadap turnover intention karyawan, yang berarti semakin tinggi rasa peduli terhadap keberlangsungan perusahaan akan mengurangi keinginan karyawan untuk keluar. Begitu juga dalam penelitian Iqbal et al. (2014) dijelaskan bahwa komitmen yang 
tinggi berdampak pada turnover yang rendah. Dijelaskan bahwa karyawan yang memiliki komitmen tinggi lebih suka untuk tinggal dan tetap bekerja daripada meninggalkan organisasi. Rendahnya komitmen yang dimiliki karyawan untuk memberikan kontribusi bagi kemajuan perusahaan merupakan salah satu penyebab keinginan karyawan keluar dari perusahaan (Iqbal et al., 2014).

Komitmen organisasional cenderung akan memberikan pengaruh positif terhadap karyawan dalam berpikir sehingga komitmen organisasional akan dapat mencegah karyawan pergi meninggalkan perusahaan untuk tetap berada dalam posisinya yang aman. Jaramillo (2004) berpendapat bahwa ketika karyawan memiliki komitmen yang tinggi terhadap organisasi, sedikit kemungkinan karyawan tersebut memiliki keinginan dan alasan untuk keluar dari organisasi tersebut. Jaramillo (2004) mengemukakan hubungan negatif antara komitmen organisasional dengan turnover intention.

$\mathrm{H}_{2}$ : Komitmen organisasional berpengaruh negatif terhadap turnover intention

Berdasarkan penjelasan sebelumnya, maka dapat diajukan model penelitian yang menggambarkan hubungan antar variabel seperti terlihat pada Gambar 1.

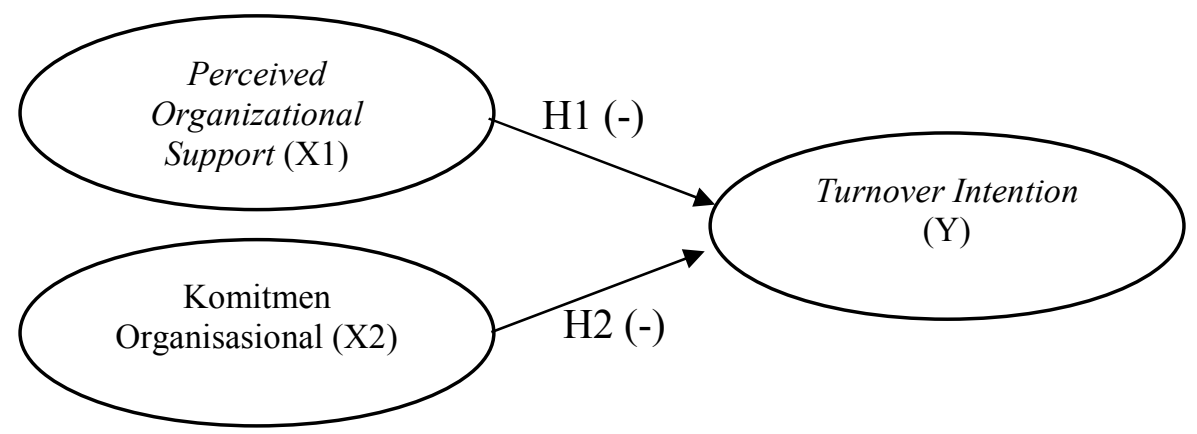

\section{Gambar 1. Model Kerangka Berfikir}

Sumber:

$H_{1}$ : $\quad$ Eisenberger et al. (1986), Rhoades dan Eisenberger (2002), Putra dkk. (2015)

$\mathrm{H}_{2}$ : $\quad$ Sutanto dan Gunawan (2013), Thakre (2015), Iqbal et al. (2014) 


\section{METODE PENELITIAN}

Penelitian ini menggunakan pendekatan asosiatif kausalitas dengan tujuan untuk mengetahui pengaruh satu atau lebih variabel bebas terhadap variabel terikat. Penelitian ini dilakukan di Ahimsa Beach Villa Jimbaran yang berlokasi di Jalan Yoga Perkanti, Jimbaran, Kuta Selatan, Kabupaten Badung, Bali. Alasan dipilihnya Ahimsa Beach Villa Jimbaran karena adanya turnover karyawan tinggi yang dapat menjadi indikasi tingginya turnover intention. Objek dalam penelitian ini yaitu perceived organizational support, komitmen organisasional, dan turnover intention.

Variabel bebas dalam penelitian ini adalah perceived organizational support (X1) dan komitmen organisasional (X2). Meyer (1991) mengemukakan komitmen organisasional adalah keadaan psikologis yang mencerminkan keinginan dan kebutuhan untuk mempertahankan keanggotaan dalam sebuah organisasi. Adapun dimensi untuk mengukur variabel komitmen oganisasional yaitu 1) komitmen afektif (affective commitment) berkaitan dengan hubungan emosional anggota dengan organisasinya, identifikasi dengan organisasi, dan keterlibatan anggota dengan kegiatan di organisasi, 2) komitmen bersinambung (continuance commitment) berkaitan dengan kesadaran anggota organisasi mengalami kerugian jika meninggalkan organisasi, dan 3) komitmen normatif (normative commitment) menggambarkan perasaan keterikatan untuk terus berada dalam organisasi.

Variabel terikat dalam penelitian ini adalah turnover intention (Y). Lum et al. (1998) mengemukakan turnover intention sebagai keinginan individu untuk keluar dari organisasi serta evaluasi mengenai posisi seseorang yang ingin keluar 
dan mencari alternatif pekerjaan lain. Adapun dimensi untuk mengukur variabel turnover intention yaitu 1) keinginan meninggalkan perusahaan yang muncul dari hasil pemikiran karyawan itu sendiri, 2) keinginan untuk mencari pekerjaan baru akibat adanya ketidaksesuaian antara apa yang diinginkan dan diharapkan ketika karyawan tersebut bekerja di perusahaanya sekarang, dan 3) keinginan meninggalkan perusahaan untuk mencari pekerjaan baru pada perusahaan lain dalam beberapa bulan mendatang yang dianggap dapat memenuhi kebutuhan hidupnya.

Populasi penelitian ini adalah seluruh karyawan Ahimsa Beach Villa yang berjumlah 84 orang. Sampel ditentukan dengan menggunakan teknik sampel jenuh. Dengan demikian jumlah sampel dalam penelitian ini berjumlah 84 orang. Tabel 2. memaparkan distribusi karyawan yang menjadi responden dalam penelitian ini.

Metode pengumpulan data awal dalam penelitian ini dilakukan dengan cara wawancara yaitu melakukan pengumpulan data dengan cara tanya jawab secara langsung dengan Operation Manager Ahisma Beach Villa Jimbaran yang berkaitan dengan turnover intention. Selain wawancara, pengumpulan data juga dilakukan menggunakan kuesioner, yaitu metode pengumpulan data dengan menyebarkan daftar pertanyaan secara tertulis kepada responden.

Tabel 2.

Populasi, sampel, dan status tenaga kerja Ahimsa Beach Villa Jimbaran

\begin{tabular}{|c|c|c|c|c|}
\hline \multirow[t]{2}{*}{ No } & \multirow[t]{2}{*}{ Departemen } & \multirow{2}{*}{$\begin{array}{l}\text { Populasi Dan } \\
\text { Sampel }\end{array}$} & \multicolumn{2}{|c|}{ Status Tenaga Kerja } \\
\hline & & & Tetap & Kontrak \\
\hline 1. & Sales \& Marketing & 5 & 5 & - \\
\hline 2. & Accounting & 4 & 4 & - \\
\hline 3. & Front Office & 18 & 15 & 3 \\
\hline 4. & Housekeeping & 24 & 20 & 4 \\
\hline
\end{tabular}


Lanjutan Tabel 2.

\begin{tabular}{|c|c|c|c|c|}
\hline \multirow[t]{2}{*}{ No } & \multirow[t]{2}{*}{ Departemen } & \multirow{2}{*}{$\begin{array}{c}\text { Populasi Dan } \\
\text { Sampel }\end{array}$} & \multicolumn{2}{|c|}{ Status Tenaga Kerja } \\
\hline & & & Tetap & Kontrak \\
\hline 5. & Engineering & 15 & 13 & 2 \\
\hline \multirow[t]{2}{*}{6.} & Security & 18 & 18 & - \\
\hline & Jumlah & 84 & 75 & 9 \\
\hline
\end{tabular}

Sumber: Ahimsa Beach Villa Jimbaran, 2016

Teknik analisis data yang digunakan dalam penelitian ini adalah Regresi

Linier Berganda. Model regresi linier berganda dalam penelitian ini digunakan untuk mengetahui pengaruh perceived organizational support dan komitmen organisasional terhadap turnover intention. Menurut Sugiyono (2013) Analisis regresi linier berganda, dirumuskan sebagai berikut.

$$
\mathrm{Y}=\alpha+\beta_{1} \mathrm{X}_{1}+\beta_{2} \mathrm{X}_{2}+\mu
$$

Keterangan:

$$
\begin{array}{ll}
\mathrm{Y} & =\text { turnover intention } \\
\mathrm{X}_{1} & =\text { perceived organizational support } \\
\mathrm{X}_{2} & =\text { komitmen organisasional } \\
\alpha & =\text { konstanta } \\
\beta_{1}-\beta_{2} & =\text { koefisien regresi variabel bebas } \\
\mu & =\text { error/variabel lain yang tidak teridentifikasi dalam model }
\end{array}
$$

\section{HASIL DAN PEMBAHASAN}

Ahimsa Beach Villa Jimbaran yang terletak di Jalan Yoga Perkhanti Jimbaran, Kecamatan Kuta Selatan Kabupaten Badung Bali mulai beroperasi sejak tahun 2006. Perusahaan ini memiliki sebelas villa pribadi mulai dari satu sampai tiga buah kamar tidur. One-Bedroom Villa dengan luas $220 \mathrm{~m} 2$ dengan total 7 buah kamar vila, Two-Bedroom Villa dengan luas $320 \mathrm{~m} 2$ dengan total 2 buah kamar vila, dan Three-Bedroom Villa dengan luas $380 \mathrm{~m} 2$ dengan total 2 buah kamar. Perbedaan setiap villa yaitu jumlah tempat tidur, segi luas kamar, 
serta fasilitasnya. Villa ini dibangun oleh Bapak Made Sukiarto pada tahun 2006 dengan menggunakan modal sendiri.

Karakteristik responden merupakan data yang dikumpulkan untuk mengetahui profil penelitian. Dari hasil penelitian yang dilakukan terhadap karyawan Ahimsa Beach Villa, maka dapat diketahui gambaran karakteristik responden yang meliputi tiga aspek, yaitu jenis kelamin, tingkat umur, dan masa kerja seperti terlihat pada Tabel 3.

Tabel 3.

Karakteristik Responden

\begin{tabular}{cccc}
\hline No & Jenis Kelamin & Orang & Jumlah \\
& Laki-Laki & 58 & Persentase (\%) \\
\hline 1 & Perempuan & 26 & 69,1 \\
& Jumlah & 84 & 30,9 \\
No & Umur (Tahun) & & 100 \\
1 & $18-25$ & 27 & \\
2 & $26-33$ & 31 & 32,2 \\
3 & $>34$ & 26 & 36,9 \\
& Jumlah & 84 & 30,9 \\
No & Masa Kerja (Tahun) & & 100 \\
1 & $1-5$ & 53 & 63,1 \\
2 & $6-10$ & 31 & 36,9 \\
& Jumlah & 84 & 100 \\
\hline
\end{tabular}

Sumber: Ahimsa Beach Villa, 2016

Tabel 3. menunjukkan bahwa sebagian besar karyawan Ahimsa Beach Villa berjenis kelamin laki-laki (58 orang atau 69,1\%). Hal ini dikarenakan banyak bidang pekerjaan di vila tersebut cukup berat misalnya di bagian housekeeping, security, dan engineering sehingga pihak vila lebih banyak mempekerjakn karyawan laki-laki. Sebagian besar karyawan Ahimsa Beach Villa berusia 26-33 (31 orang atau 36,9\%). Berdasarkan persentase, sebagian besar karyawan Ahimsa Beach Villa memiliki masa kerja 1-5 tahun yakni sebanyak 53 orang $(63,1 \%)$. 
Instrumen dikatakan valid jika korelasi antar skor faktor dengan skor total bernilai positif dan nilainya lebih dari sama dengan $0,30(\mathrm{r} \geq 0,3)$. Hasil uji validitas pada Tabel 4. menunjukkan bahwa seluruh variabel memiliki nilai koefisien korelasi dengan skor total seluruh butir pernyataan lebih besar dari 0,30. Hal ini menunjukkan bahwa butir-butir pernyataan dalam instrumen penelitian tersebut valid.

Tabel 4.

Hasil Uji Validitas

\begin{tabular}{|c|c|c|c|c|}
\hline No & Variabel & Indikator & Korelasi & Keterangan \\
\hline \multirow[t]{8}{*}{1} & Perceived Organizational & $\mathrm{X}_{1}$ & 0,669 & Valid \\
\hline & Support (X1) & $\mathrm{X}_{2}$ & 0,688 & Valid \\
\hline & & $\mathrm{X}_{3}$ & 0,641 & Valid \\
\hline & & $\mathrm{X}_{4}$ & 0,788 & Valid \\
\hline & & $\mathrm{X}_{5}$ & 0,701 & Valid \\
\hline & & $\mathrm{X}_{6}$ & 0,679 & Valid \\
\hline & & $\mathrm{X}_{7}$ & 0,692 & Valid \\
\hline & & $\mathrm{X}_{8}$ & 0,634 & Valid \\
\hline \multirow[t]{6}{*}{2} & Komitmen Organisasional (X2) & $\mathrm{X}_{1}$ & 0,788 & Valid \\
\hline & & $\mathrm{X}_{2}$ & 0,752 & Valid \\
\hline & & $\mathrm{X}_{3}$ & 0,830 & Valid \\
\hline & & $\mathrm{X}_{4}$ & 0,801 & Valid \\
\hline & & $\mathrm{X}_{5}$ & 0,883 & Valid \\
\hline & & $\mathrm{X}_{6}$ & 0,829 & Valid \\
\hline \multirow[t]{4}{*}{3} & Turnover Intention (Y) & $\mathrm{Y}_{1}$ & 0,798 & Valid \\
\hline & & $\mathrm{Y}_{2}$ & 0,801 & Valid \\
\hline & & $\mathrm{Y}_{3}$ & 0,770 & Valid \\
\hline & & $\mathrm{Y}_{4}$ & 0,862 & Valid \\
\hline
\end{tabular}

Sumber : Data Diolah, 2017

Uji reliabilitas menunjukkan sejauh mana suatu alat pengukur dapat dipercaya atau dapat diandalkan. Suatu instrumen dikatakan reliabel, jika instrumen tersebut memiliki nilai Cronbach's Alpha lebih dari atau sama dengan $0,60(\mathrm{r} \geq 0,6)$. Hasil uji reliabilitas dalam penelitian ini menunjukkan bahwa instrumen penelitian yaitu perceived organizational support, komitmen organisasional dan turnover intention memiliki koefisien Cronbach's Alpha lebih dari atau sama dengan 0,60 . Hal ini berarti semua variabel adalah reliabel. 
Tabel 5.

Hasil Uji Reliabilitas

\begin{tabular}{clcc}
\hline No. & \multicolumn{1}{c}{ Variabel } & Cronbach's Alpha & Keterangan \\
\hline 1 & Perceived Organizational Support (X1) & 0,856 & Reliabel \\
2 & Komitmen Organisasional (X2) & 0,899 & Reliabel \\
3 & Turnover Intention $(\mathrm{Y})$ & 0,822 & Reliabel \\
\hline Sumber: & Data Diolah, 2017
\end{tabular}

Hasil analisis deskriptif pada Tabel 6. menunjukkan jawaban responden pada variabel perceived organizational support secara keseluruhan memiliki nilai rata-rata 4,10 yang berarti perceived organizational support yang dirasakan karyawan Ahimsa Beach Villa termasuk dalam kriteria tinggi. Tabel 6 . menunjukkan bahwa terdapat satu indikator yang memiliki rata-rata tertinggi yang perlu diperhatikan oleh perusahaan yang ditunjukkan pada pernyataan "Organisasi menghargai usaha ekstra yang telah saya berikan” yaitu 4,21. Hal ini berarti karyawan Ahimsa Beach Villa merasa organisasi sudah menghargai usaha ekstra yang telah diberikan karyawan kepada perusahaan. Selanjutnya terdapat satu indikator yang memiliki rata-rata terendah yang perlu diperhatikan oleh perusahaan yang ditunjukkan pada pernyataan "Organisasi peduli dengan kepuasan kerja saya" yaitu 4,04. Hal ini berarti pihak manajemen Ahimsa Beach Villa belum sepenuhnya peduli dengan kepuasan kerja karyawannya.

Tabel 6.

Deskripsi Jawaban Responden Perceived Organizational Support

\begin{tabular}{|c|c|c|c|c|c|c|c|c|}
\hline \multirow{2}{*}{ No } & \multirow{2}{*}{ Pernyataan } & \multicolumn{5}{|c|}{ Proporsi Jawaban Responden } & \multirow{2}{*}{$\begin{array}{c}\text { Rata- } \\
\text { Rata } \\
(\%) \\
\end{array}$} & \multirow{2}{*}{ Kriteria } \\
\hline & & STS & TS & $\mathbf{N}$ & $\mathbf{S}$ & SS & & \\
\hline 1 & $\begin{array}{l}\text { Organisasi menghargai } \\
\text { kontribusi saya }\end{array}$ & 0 & 2 & 8 & 58 & 16 & 4,05 & Tinggi \\
\hline 2 & $\begin{array}{l}\text { Organisasi menghargai } \\
\text { usaha ekstra yang telah saya } \\
\text { berikan }\end{array}$ & 0 & 2 & 3 & 54 & 25 & 4,21 & Tinggi \\
\hline 3 & $\begin{array}{l}\text { Organisasi menanggapi } \\
\text { dengan baik jika saya } \\
\text { memiliki keluhan }\end{array}$ & 0 & 2 & 4 & 53 & 25 & 4,20 & Tinggi \\
\hline
\end{tabular}


Lanjutan Tabel 6.

\begin{tabular}{|c|c|c|c|c|c|c|c|c|}
\hline \multirow[t]{2}{*}{ No } & \multirow[t]{2}{*}{ Pernyataan } & \multicolumn{5}{|c|}{ Proporsi Jawaban Responden } & \multirow{2}{*}{$\begin{array}{c}\text { Rata- } \\
\text { Rata } \\
(\%)\end{array}$} & \multirow[t]{2}{*}{ Kriteria } \\
\hline & & STS & TS & $\mathbf{N}$ & $\mathbf{S}$ & SS & & \\
\hline 4 & $\begin{array}{l}\text { Organisasi peduli dengan } \\
\text { kesejahteraan saya }\end{array}$ & 0 & 4 & 2 & 56 & 22 & 4,14 & Tinggi \\
\hline 5 & $\begin{array}{l}\text { Organisasi memberitahu } \\
\text { apabila pekerjaan saya tidak } \\
\text { dilakukan dengan baik }\end{array}$ & 0 & 3 & 8 & 51 & 22 & 4,10 & Tinggi \\
\hline 6 & $\begin{array}{l}\text { Organisasi peduli dengan } \\
\text { kepuasan kerja saya }\end{array}$ & 0 & 2 & 5 & 65 & 12 & 4,04 & Tinggi \\
\hline 7 & $\begin{array}{l}\text { Organisasi menunjukkan } \\
\text { sikap perhatian yang besar } \\
\text { kepada saya }\end{array}$ & 0 & 1 & 9 & 56 & 18 & 4,08 & Tinggi \\
\hline 8 & $\begin{array}{l}\text { Organisasi bangga atas } \\
\text { keberhasilan saya }\end{array}$ & 0 & 2 & 7 & 54 & 21 & 4,12 & Tinggi \\
\hline & \multicolumn{6}{|c|}{ Rata-Rata } & 4,10 & Tinggi \\
\hline
\end{tabular}

Sumber: Data Diolah, 2017

Tabel 7. menunjukkan jawaban responden pada variabel komitmen organisasional secara keseluruhan memiliki nilai rata-rata 3,96 yang berarti komitmen organisasional yang dirasakan karyawan Ahimsa Beach Villa termasuk dalam kriteria tinggi.

Tabel 7. menunjukkan terdapat satu indikator yang memiliki rata-rata tertinggi yang perlu diperhatikan oleh perusahaan yang ditunjukkan pada pernyataan "Saya berkeinginan kuat untuk tetap sebagai anggota organisasi" yaitu 4,07. Hal ini berarti karyawan Ahimsa Beach Villa berkomitmen kuat untuk tetap sebagai anggota organisasi. Selanjutnya terdapat satu indikator yang memiliki rata-rata terendah yang perlu diperhatikan oleh perusahaan yang ditunjukkan pada pernyataan "Saya yakin akan tujuan organisasi" yaitu 3,90.

Hal ini di khawatirkan oleh perusahaan karena meskipun perusahaan sudah memberikan jabatan tinggi, tetapi jika karyawan tidak yakin dan fokus pada tujuan organisasi akan berdampak buruk bagi perusahaan. 
Tabel 7.

Deskripsi Jawaban Responden Variabel Komitmen Organisasional

\begin{tabular}{|c|c|c|c|c|c|c|c|c|}
\hline \multirow{2}{*}{ No } & \multirow{2}{*}{ Pernyataan } & \multicolumn{5}{|c|}{ Proporsi Jawaban Responden } & \multirow{2}{*}{ Rata-Rata (\%) } & \multirow{2}{*}{ Kriteria } \\
\hline & & STS & TS & $\mathbf{N}$ & $\mathbf{S}$ & SS & & \\
\hline 1 & $\begin{array}{l}\text { Saya berkeinginan kuat } \\
\text { untuk tetap sebagai } \\
\text { anggota organisasi }\end{array}$ & 0 & 3 & 8 & 53 & 20 & 4,07 & Tinggi \\
\hline 2 & $\begin{array}{l}\text { Saya berkeinginan untuk } \\
\text { berusaha keras sesuai } \\
\text { keinginan organisasi }\end{array}$ & 0 & 3 & 8 & 55 & 18 & 4,05 & Tinggi \\
\hline 3 & $\begin{array}{l}\text { Saya menerima nilai-nilai } \\
\text { organisasi }\end{array}$ & 0 & 5 & 9 & 56 & 14 & 3,94 & Tinggi \\
\hline 4 & $\begin{array}{l}\text { Saya sulit meninggalkan } \\
\text { perusahaan ini karena } \\
\text { takut tidak mendapatkan } \\
\text { kesempatan kerja di } \\
\text { tempat lain }\end{array}$ & 0 & 4 & 10 & 58 & 12 & 3,93 & Tinggi \\
\hline 5 & $\begin{array}{l}\text { Saya yakin akan nilai-nilai } \\
\text { organisasi }\end{array}$ & 0 & 5 & 11 & 54 & 14 & 3,92 & Tinggi \\
\hline 6 & $\begin{array}{l}\text { Saya yakin akan tujuan } \\
\text { organisasi }\end{array}$ & 0 & 5 & 14 & 49 & 16 & 3,90 & Tinggi \\
\hline & \multicolumn{6}{|c|}{ Rata-Rata } & 3,96 & Tinggi \\
\hline
\end{tabular}

Tabel 8. menunjukkan jawaban responden pada variabel turnover intention secara keseluruhan memiliki nilai rata-rata 2,23 yang berarti turnover intention yang dirasakan karyawan Ahimsa Beach Villa termasuk dalam kriteria rendah. Namun terdapat satu indikator yang berada diatas rata-rata yang perlu diperhatikan oleh perusahaan yang ditunjukkan pada pernyataan "Saya berkeinginan meninggalkan organisasi bila ada kesempatan" yang memiliki nilai rata-rata tertinggi dibandingkan pernyataan lainnya yaitu 2,46. Hal ini berarti karyawan Ahimsa Beach Villa mempunyai keinginan yang besar untuk meninggalkan organisasi sekarang dan memilih untuk bekerja pada perusahaan lain bila ada kesempatan untuk keluar dari perusahaan. Selanjutnya terdapat satu indikator yang berada dibawah rata-rata yang perlu diperhatikan oleh perusahaan yang ditunjukkan pada pernyataan "Saya berkeinginan untuk meninggalkan 
organisasi dalam waktu dekat" yang memiliki rata-rata terendah dibandingkan pernyataan lainnya yaitu 2,08. Hal ini berarti kemungkinan karyawan untuk meninggalkan organisasi dalam waktu dekat tergolong kecil.

Tabel 8.

Deskripsi Jawaban Responden Variabel Turnover Intention

\begin{tabular}{|c|c|c|c|c|c|c|c|c|}
\hline \multirow{2}{*}{ No } & \multirow{2}{*}{ Pernyataan } & \multicolumn{5}{|c|}{ Proporsi Jawaban Responden } & \multirow{2}{*}{ Rata-Rata (\%) } & \multirow{2}{*}{ Kriteria } \\
\hline & & STS & TS & $\mathbf{N}$ & $\mathbf{S}$ & SS & & \\
\hline 1 & $\begin{array}{l}\text { Saya berfikir untuk } \\
\text { meninggalkan organisasi }\end{array}$ & 12 & 48 & 18 & 6 & 0 & 2,21 & Rendah \\
\hline 2 & $\begin{array}{l}\text { Saya berkeinginan mencari } \\
\text { pekerjaan baru di } \\
\text { organisasi lain }\end{array}$ & 15 & 48 & 15 & 5 & 1 & 2,15 & Rendah \\
\hline 3 & $\begin{array}{l}\text { Saya berkeinginan untuk } \\
\text { meninggalkan organisasi } \\
\text { dalam waktu dekat }\end{array}$ & 15 & 51 & 15 & 2 & 1 & 2,08 & Rendah \\
\hline 4 & $\begin{array}{l}\text { Saya berkeinginan } \\
\text { meninggalkan organisasi } \\
\text { bila ada kesempatan }\end{array}$ & 11 & 38 & 22 & 11 & 2 & 2,46 & Rendah \\
\hline \multicolumn{7}{|c|}{ Rata-Rata } & 2,23 & Rendah \\
\hline
\end{tabular}

Uji asumsi klasik dilakukan untuk menguji kelayakan model yang dibuat sebelum digunakan untuk memprediksi, adapun uji asumsi klasik meliputi: uji normalitas, uji multikolinearitas dan uji heteroskedastisitas. Hasil uji normalitas dalam penelitian ini menunjukkan bahwa nilai Kolmogorov Sminarnov (K-S) sebesar 0,556, sedangkan nilai Asymp. Sig. (2-tailed) sebesar 0,917. Hasil tersebut mengindikasikan bahwa model persamaan regresi tersebut berdistribusi normal karena nilai Asymp. Sig. (2-tailed) 0,917 lebih besar dari nilai alpha 0,05.

Tabel 9.

Hasil Uji Normalitas

\begin{tabular}{cc}
\hline & Unstandardized Residual \\
\hline N & 84 \\
Kolmogorov-Smirnov $Z$ & 0,556 \\
Asymp.Sig.(2-tailed) & 0,917 \\
\hline
\end{tabular}
Sumber: Data Diolah, 2017 
Uji multikolinearitas bertujuan untuk menguji apakah pada model regresi ditemukan adanya korelasi antar variabel bebas. Adanya multikolinearitas dapat dilihat dari nilai tolerance atau variance inflation factor (VIF). Jika nilai tolerance lebih dari $10 \%$ atau VIF kurang dari 10, maka dikatakan tidak ada multikolinearitas. Hasil uji multikolinieritas dalam penelitian ini menunjukkan bahwa nilai tolerance dan VIF dari seluruh variabel memiliki nilai tolerance untuk setiap variabel lebih besar dari 10\% dan nilai VIF lebih kecil dari 10 yang berarti model persamaan regresi bebas dari multikolinearitas.

Tabel 10.

Hasil Uji Multikolinearitas

\begin{tabular}{clcc}
\hline \multirow{2}{*}{ No } & \multirow{2}{*}{ Model } & \multicolumn{2}{c}{ Collinearity Statistic } \\
\cline { 3 - 4 } & & Tolerance & VIF \\
\hline 1 & Perceived Organizational Support & 0.618 & 1.617 \\
2 & Komitmen Organisasional & 0.618 & 1.617 \\
\hline \multicolumn{2}{l}{ Sumber: Data Diolah, 2017} &
\end{tabular}

Hasil uji heteroskedastisitas dalam penelitian ini menunjukkan bahwa nilai Signifikansi dari variabel perceived organizational support dan komitmen organisasional, masing-masing sebesar 0,869 dan 0,209. Nilai tersebut lebih besar dari 0,05 yang berarti tidak terdapat pengaruh antara variabel bebas terhadap absolute residual. Dengan demikian, model penelitian tidak mengandung gejala heteroskedastisitas.

Tabel 11.

Hasil Uji Heteroskedastisitas (Uji Glejser)

\begin{tabular}{lrccrrr}
\hline & \multicolumn{2}{c}{$\begin{array}{c}\text { Unstandardized } \\
\text { Coefficients }\end{array}$} & $\begin{array}{c}\text { Standardized } \\
\text { Coefficients }\end{array}$ & \multirow{2}{*}{ t } & Sig. \\
\cline { 2 - 5 } & \multicolumn{1}{c}{ B } & Std. Error & Beta & & \\
\hline (Constant) & $-0,227$ & 1.136 & & $-0,200$ & 0,842 \\
Perceived Organizational Support & 0,007 & 0,043 & 0,023 & 0,166 & 0,869 \\
Komitmen Organisasional & 0,058 & 0,046 & 0,176 & 1.266 & 0,209 \\
\hline
\end{tabular}


Pada Tabel 11. dapat dilihat bahwa nilai Sig. dari variabel perceived organizational support dan komitmen organisasional, masing-masing sebesar 0,869 dan 0,209 . Nilai tersebut lebih besar dari 0,05 yang berarti tidak terdapat pengaruh antara variabel bebas terhadap absolute residual. Dengan demikian, model penelitian tidak mengandung gejala heteroskedastisitas.

Analisis regresi linier berganda bertujuan untuk mengetahui ketergantungan suatu variabel terikat dengan satu atau lebih variabel bebas. Analisis ini juga dapat menduga arah dari hubungan tersebut serta mengukur derajat keeratan hubungan antara satu variabel terikat dengan satu variabel bebas. Adapun hasil analisis regresi dengan program Statitical Pacage of Social Science (SPSS) versi 15.0 for Windows dapat dilihat pada Tabel 12.

Tabel 12.

Rangkuman Hasil Analisis Regresi Linier Berganda

\begin{tabular}{|c|c|c|c|c|c|}
\hline & \multicolumn{2}{|c|}{$\begin{array}{c}\text { Unstandardized } \\
\text { Coefficients }\end{array}$} & \multirow{2}{*}{$\begin{array}{c}\text { Standardized } \\
\text { Coefficients } \\
\text { Beta }\end{array}$} & \multirow[b]{2}{*}{$\mathbf{t}$} & \multirow[b]{2}{*}{ Sig. } \\
\hline & $\mathbf{B}$ & Std. Error & & & \\
\hline$\overline{\text { (Constant) }}$ & 24.629 & 1.826 & & 13.487 & 0,000 \\
\hline Perceived Organizational Support & $-0,134$ & 0,069 & $-0,185$ & -1.946 & 0,055 \\
\hline Komitmen Organisasional & $-0,475$ & 0,074 & $-0,611$ & -6.432 & 0,000 \\
\hline R Square & & & & & 0,548 \\
\hline F Statistik & & & & & 49,027 \\
\hline Signifikansi & & & & & 0,000 \\
\hline
\end{tabular}

Sumber: Data Diolah, 2017

Berdasarkan Tabel 12. dapat ditulis persamaan regresi linier berganda sebagai berikut: $\mathrm{Y}=24,629-0,134 \mathrm{X}_{1}-0,475 \mathrm{X}_{2}$

Berdasarkan Tabel 13. nilai determinasi total sebesar 0,548 mempunyai arti bahwa sebesar 54,8\% variasi turnover intention dipengaruhi oleh variasi perceived organizational support, dan komitmen organisasional, sedangkan sisanya sebesar 45,2\% djelaskan oleh faktor lain yang tidak dimasukkan ke dalam model. 
Tabel 13.

Hasil Uji Koefisien Determinasi $\left(\mathbf{R}^{\mathbf{2}}\right)$

\begin{tabular}{rrrrrr}
\hline $\mathrm{R}$ & $\mathrm{R}$ Square & Adjusted $\mathrm{R}$ Square & $\begin{array}{c}\text { Std. Error of the } \\
\text { Estimate }\end{array}$ & Durbin-Watson \\
\hline 0,740 & 0,548 & 0,536 & & 1,831 & 1,973 \\
\hline
\end{tabular}

Sumber: Data Diolah, 2017

Model regresi penelitian ini dikatakan layak atau variabel bebas mampu menjelaskan variabel terikat dilihat dari hasil uji $\mathrm{F}$ dengan nilai signifikan lebih kecil dari alpha yaitu $0,05($ Anova $<\alpha=0,05)$.

Tabel 14.

\begin{tabular}{lrrrrr}
\multicolumn{7}{c}{ Hasil Uji F } \\
\hline & Sum of Squares & \multicolumn{1}{c}{ Df } & Mean Square & \multicolumn{1}{c}{ F } & \multicolumn{1}{c}{ Sig. } \\
\hline Regression & 328.800 & 2 & 164.400 & 49.027 & 0,000 \\
Residual & 271.616 & 81 & 3.353 & & \\
Total & $\mathbf{6 0 0 . 4 1 7}$ & $\mathbf{8 3}$ & & & \\
\hline Sumber & \multicolumn{6}{c}{} & & &
\end{tabular}

Sumber: Data Diolah, 2017

Tabel 14. menunjukkan bahwa nilai Sig. sebesar 0,000 lebih kecil dari nilai $\alpha=0,05$ yang artinya model regresi linier berganda pada penelitian ini layak digunakan sebagai alat analisis untuk menguji variabel bebas terhadap variabel terikat.

Berdasarkan hasil analisis pada Tabel 12. menunjukkan bahwa nilai Sig. $\mathrm{t}$ sebesar 0,055 dengan koefisien regresi sebesar $-0,134$. Nilai Sig. t 0,055 $>0,05$ mengindikasikan bahwa $\mathrm{H}_{0}$ diterima dan $\mathrm{H}_{1}$ ditolak. Hasil ini mempunyai arti bahwa perceived organizational support tidak berpengaruh secara signifikan terhadap turnover intention. Dengan kata lain, POS tidak berkontribusi terhadap variasi (tinggi - rendahnya) turnover intention karyawan Ahimsa Beach Villa Jimbaran, hal ini mengidentifikasikan bahwa keinginan keluarnya karyawan bukan semata-mata dikarenakan ada atau tidaknya POS karyawan di Ahimsa Beach Villa Jimbaran tersebut. Namun, mungkin ada alasan lain yang lebih berpengaruh dengan keinginan keluarnya karyawan. 
Tidak ada pengaruh POS terhadap turnover intention juga bisa disebabkan karena $63,1 \%$ dari responden memiliki masa kerja kurang dari 5 tahun sehingga ada kemungkinan karyawan masih memiliki peluang untuk berkembang lebih baik di tempat kerja yang lain sesuai harapannya. Hasil penelitian ini bertolak belakang dengan penelitian sebelumnya oleh Rhoades dan Eisenberger (2002), Putra dkk. (2015) dimana dalam penelitian tersebut menemukan adanya pengaruh signifikan POS terhadap turnover intention.

Berdasarkan jawaban responden yang didapat dari hasil penyebaran kuesioner yang meliputi delapan pernyataan mengenai variabel perceived organizational support, dapat diketahui butir pernyataan dengan rata-rata skor tertinggi yaitu pernyataan $\mathrm{X}_{1.2}$, “organisasi menghargai usaha ekstra yang telah saya berikan". Hal ini menunjukan karyawan Ahimsa Beach Villa merasa organisasi sudah menghargai usaha ektra yang telah diberikan karyawan kepada perusahaan. Bila karyawan merasakan dukungan dari organisasi dan dukungan itu sesuai dengan norma, maka karyawan dengan sendirinya akan memiliki ikatan emosional untuk memenuhi kewajibannya pada organisasi. Namun, tidak menutup kemungkinan karyawan tidak memiliki keinginan untuk keluar dari perusahaan. Meski dalam penelitian ini perceived organizational support tidak berpengaruh terhadap turnover intention namun pihak perusahaan haruslah menyikapinya sebagai suatu fenomena dan perilaku manusia yang penting di dalam kehidupan suatu perusahaan, baik dari sudut pandang individu maupun sosial. Mengingat bahwa tingkat keinginan berpindah karyawan tersebut bisa berdampak besar bagi perusahaan dan individu yang bersangkutan (Putra dkk., 2015). Turnover 
Intention merupakan masalah yang sering timbul pada sebuah organisasi yang menyangkut keinginan keluarnya karyawan dalam sebuah organisasi, turnover intention menjadi masalah penting karena biaya untuk mengganti individu yang keluar akan berdampak pada pendapatan perusahaan (Putra dkk., 2015).

Berdasarkan analisis data tampak bahwa komitmen organisasional berpengaruh negatif dan signifikan terhadap turnover intention. Hal ini berarti semakin tinggi komitmen organisasional yang dirasakan karyawan akan dapat menurunkan keinginan karyawan untuk keluar dari perusahaanya. Pada hasil penelitian Sutanto dan Gunawan (2013) menemukan komitmen organisasional berpengaruh negatif dan signifikan pada turnover intention. Thakre (2015) yang meneliti hubungan komitmen organisasional terhadap turnover intention menemukan hubungan negatif antara turnover intention dengan komitmen organisasional, dimana terdapat indikasi turnover yang tinggi menandakan komitmen yang rendah, begitu juga dalam penelitian (Iqbal et al., 2014) menemukan hubungan komitmen tinggi dengan niat yang rendah untuk berhenti dari organisasi.

Berdasarkan jawaban responden yang didapat dari hasil penyebaran kuesioner yang meliputi delapan pernyataan mengenai variabel komitmen organisasional, dapat diketahui butir pernyataan dengan rata-rata skor tertinggi yaitu pernyataan $\mathrm{X}_{2.1}$, "saya berkeinginan kuat untuk tetap sebagai anggota organisasi”. Hal ini karyawan Ahimsa Beach Villa berkomitmen kuat untuk tetap sebagai anggota organisasi. Dalam dunia bisnis, komitmen seseorang terhadap organisasi merupakan isu yang sangat penting. Oleh karena fungsinya yang sangat 
penting tersebut, beberapa organisasi dan perusahaan memasukkan unsur komitmen organisasi sebagai salah satu syarat seseorang untuk memegang suatu jabatan atau posisi dalam perusahaan (Handaru dan Nailul, 2012). Menurut Thakre (2015) ketiadaan komitmen akan dapat menurunkan efektifitas organisasi, karyawan yang berkomitmen tidak mungkin keluar dan menerima pekerjaan lain, dengan demikian biaya pergantian tinggi tidak terjadi.

\section{SIMPULAN DAN SARAN}

Berdasarkan hasil analisis penelitian dan hasil pembahasan diatas, maka dapat ditarik beberapa simpulan yaitu variabel perceived organizational support tidak berpengaruh terhadap turnover intention. Perceived organizational support tidak berpengaruh besar terhadap turnover intention dan masih banyak faktorfaktor lain yang mempengaruhi turnover intention karyawan di Ahimsa Beach Villa. Penelitian pada dasarnya bersifat objektif, bukan subjektifitas menurut pakar tertentu. Jadi, penelitian sejatinya merupakan paradigma yang realistis sesuai fakta di lapangan, bukan paradigma idealis yang mengharuskan bahwa penelitian harus sama persis dengan teori yang ada (misalnya jika teori berpengaruh signifikan maka dipenelitian ini juga harus berpengaruh signifikan). Sehingga dapat dikatakan bahwa hipotesa yang didasarkan pada penelitianpenelitian sebelumnya tidak selalu sama hasilnya dengan penelitian ini. Kemungkinan karena perbedaan-perbedaan latar belakang, indikator, pernyataanpernyataan responden yang berbeda, dan lain sebagainya.

Komitmen organisasional berpengaruh negatif dan signifikan terhadap turnover intention. Hal ini menunjukkan bahwa semakin tinggi tingkat komitmen 
organisasional karyawan maka semakin rendah tingkat turnover yang dirasakan karyawan pada perusahaan tersebut, maka sebaiknya perusahaan memberikan pengawasan yang baik kepada seluruh karyawan dan juga memberi kesempatan karyawan untuk terlibat dalam pemecahan masalah yang sedang dihadapi, agar dapat meningkatkan kepuasan kerja karyawan.

Berdasarkan pembahasan, hasil analisis penelitian dan simpulan maka beberapa saran yang dapat diberikan yaitu dalam penelitian ini ditemukan bahwa perceived organizational support tidak berpengaruh terhadap turnover intention, artinya terdapat faktor lain yang lebih mempengaruhi perceived organizational support dan turnover intention karyawan. Seperti yang ditunjukkan pernyataan “Organisasi peduli dengan kepuasan kerja saya” yang memiliki rata-rata terendah, hal ini berarti pihak manajemen Ahimsa Beach Villa belum sepenuhnya peduli dengan kepuasan kerja karyawannya. Jika organisasi tidak peduli dengan kepuasan kerja karyawannya, maka karyawan merasakan tugas-tugas yang diberikan perusahaan sebagai sesuatu yang tidak menyenangkan dan memperlihatkan hasil kerja yang tidak efektif untuk organisasi.

Berdasarkan hasil analisis deskriptif mengenai variabel komitmen organisasional didapat hasil skor tertinggi pada peryataan pertama yaitu "saya berkeinginan kuat untuk tetap sebagai anggota organisasi”. Oleh sebab itu perusahaan diharapkan mampu mempertahankan dan mendukung kinerja karyawan agar mereka selalu berkeinginan kuat untuk tetap bekerja di perusahaan.

Penelitian ini hanya sebatas meneliti mengenai perceived organizational support, komitmen organisasional dan turnover intention. Penelitian selanjutnya 
diharapkan untuk bisa menambah variabel-variabel lain karena penelitian ini hanya memandang turnover intention dipengaruhi perceived organizational support dan komitmen organisasional, namun tidak menutup kemungkinan munculnya faktor lain seperti lingkungan kerja fisik, kepuasan kerja, keadilan organisasional dan kepemimpinan, maupun faktor lainnya. Peneliti selanjutnya juga diharapkan untuk dapat mengambil sampel diluar lingkungan industri perhotelan misalkan industri manufaktur, perbankan, maupun industri lainnya.

\section{REFERENSI}

Andini R. 2006. Analisis Pengaruh Kepuasan Gaji, Kepuasan Kerja, Komitmen Organisasional Terhadap Turnover Intention (Studi Kasus Pada Rumah Sakit Roemani).

Eisenberger R., and Hotington R. 1986. Perceived Organizational Support. Journal of Applied Psychology. 7(3) pp: 500 - 507

Han S.J., Agustinus N., Endo K., dan Thomas K. 2012. Komitmen Afektif Dalam Organisasi Yang Dipengaruhi Perceived Organizational Support Dan Kepuasan Kerja. Jurnal Manajemen dan Kewirausahaan.14 (2) pp: 109117

Handaru W.A., dan Nailul M. 2012. Pengaruh Kepuasan Gaji Dan Komitmen Organisasi Terhadap Intensi Turnover Pada Divisi PT Jamsostek.Jurnal Riset Manajemen Sains Indonesia. 3(1) pp: 1-19

Iqbal S., Ehsan S., Muhammad R., Noreen M. 2014. The impact of organizational commitment, job satisfaction, job stress and leadership support on turnover intention in educational institutes. International Journal of Human Resource Studies. Vol. 4, No. 2

Jaramillo F. 2004. The effect of law enforcement stress on organizational commitment. Policing: An International Journal of Police Strategies And Management.28(2), pp: 321-336.

Khoiroh M.M. 2012. Tingkat worker turnover pada Multinasional Companies dan Kaitannya dengan Cultural Adjustment. JESP, 4(1), pp.5-12. 
Lum K., Clark, Raid, and Sirola. 1998. Explaning Nursing Turnover Intent: Job Statisfaction, Pay Statisfaction, or Organizational Commitmen. Journal of Organizational Behavior, 19(3) pp: $305-320$.

Maertz C.P., Rodger W.G,. Nathanael S.C., and David G.A. 2007. The Effect of Perceived Organizational Support and Perceived Supervisor Support on Employee Turnover. Journal Organizational Behaviour. Vol 28, No 8, pp. 10591075

Meyer A. 1991. A Three - Component Conzeptualization of Organizational Commitment. Human Resource Management Review. 1 pp: 61 - 89

Novaliawati K.I., Dharma S. 2013. Pengaruh Kepuasan Kerja Dan Komitmen Organisasi Terhadap Turnover Intention Pada Karyawan Pt. Mitra Andalan Niaga Nusantara Kab. Tebo. E-jurnal Bunghatta. Vol 2, No 2

Ponnu and Chuah. 2010. Organizational commitment, organizational justice and employee turnover in Malaysia. African Journal of Business Management.Vol. 4(13), pp. 2676-2692.

Putra R.G., Maria V.B., Endo W.K. 2015. Pengaruh Perceived Organizational Support Terhadap Turnover Intention Melalui Kepuasan Kerja Sebagai Variabel Mediator Di Restoran X Surabaya. Jurnal Hospitality dan Manajemen Jasa. 1 :pp: 191-202s

Rahayu S.P. 2011. Pengaruh Kepuasan Kerja Terhadap Turnover Intention Karyawan PT. X di Sidoarjo. Skripsi Fakultas Ekonomi Universitas Narotama, pp: 2-5.

Rhoades L., and Eisenberger R. 2002. Perceived Organizational Support: A Review of the Literature. Journal of Applied Psychology.87(4)pp: 698714

Ridwan dan Sunarto. 2007. Pengantar Statistika Untuk Penelitian Pendidikan, Sosial, Ekonomi, dan Bisnis. Bandung : Alfabeta.

Robbins dan Judge T. 2009. Perilaku Organisasi. Buku 1 Edisi 12. Jakarta : Salemba Empat.

Sugiyono. 2013. Metode Penelitian Bisnis. Bandung : Alfabeta.

Sutanto E., dan Gunawan C. 2013. Kepuasan Kerja, Komitmen Organisasional dan Turnover Intentions. Jurnal Mitra Ekonomi dan Manajemen Bisnis. Vol. 4(1): pp: 76-88.

Thakre N. 2015. Organizational Commitment and Turnover Intention in BPOITeS and Retail Sector Employees. Journal of Psychosocial Research. 10(1) pp: 89-98 
E-Jurnal Manajemen, Vol. 8, No. 8, $2019: 5139-5163$

Widjaja D.C., Margarita F., Fenny K. 2008. Analisis Persepsi Employee Empowerment terhadap Employee Turnover Intention di Hotel X, Kupang, Nusa Tenggara. Jurnal Manajemen Perhotelan. 4(2) pp: 72-84 